\title{
ESOPHAGEAL CONTRACTIONS, BOLUS TRANSIT AND PERCEPTION OF TRANSIT AFTER SWALLOWS OF LIQUID AND SOLID BOLUSES IN NORMAL SUBJECTS
}

\author{
Juciléia DALMAZO, Lilian Rose Otoboni APRILE and Roberto Oliveira DANTAS
}

\begin{abstract}
Context - Esophageal dysphagia is the sensation that the ingested material has a slow transit or blockage in its normal passage to the stomach. It is not always associated with motility or transit alterations. Objectives - To evaluate in normal volunteers the possibility of perception of bolus transit through the esophagus after swallows of liquid and solid boluses, the differences in esophageal contraction and transit with these boluses, and the association of transit perception with alteration of esophageal contraction and/or transit. Methods - The investigation included 11 asymptomatic volunteers, 4 men and 7 women aged 19-58 years. The subjects were evaluated in the sitting position. They performed swallows of the same volume of liquid (isotonic drink) and solid (macaroni) boluses in a random order and in duplicate. After each swallow they were asked about the sensation of bolus passage through the esophagus. Contractions and transit were evaluated simultaneously by solid state manometry and impedance. Results - Perception of bolus transit occurred only with the solid bolus. The amplitude and area under the curve of contractions were higher with swallows of the solid bolus than with swallows of the liquid bolus. The difference was more evident in swallows with no perception of transit $(n=12)$ than in swallows with perception $(n=10)$. The total bolus transit time was longer for the solid bolus than for the liquid bolus only with swallows followed by no perception of transit. Conclusion - The results suggest that the perception of esophageal transit may be the consequence of inadequate adaptation of esophageal transit and contraction to the characteristics of the swallowed bolus.
\end{abstract}

HEADINGS - Deglutition disorders. Esophagus, physiology. Food. Water.

\section{INTRODUCTION}

Esophageal dysphagia is the sensation that the ingested material has a slow transit or blockage in its normal passage on its way to the stomach ${ }^{(11)}$. It is not always associated with impairment of bolus transit or changing of proximal digestive motility ${ }^{(3,13)}$, suggesting that esophageal sensitivity may play a role in the increased perception of bolus passage ${ }^{(13)}$.

Esophageal dysphagia may be caused by obstruction of luminal flow (mechanical) or by alterations of motility in the esophageal body (neuromuscular). Dysphagia for both liquid and solid foods is more frequent in neuromuscular disease, and dysphagia for solid foods is more frequent in the presence of mechanical obstruction of the esophagus ${ }^{(11)}$. Swallows of liquid and solid boluses cause different esophageal response ${ }^{(10,12)}$ which might be associated with the perception of the bolus passage through the esophagus.

The objective of this investigation was to evaluate in normal volunteers the possibility of perception of bolus transit through the esophagus after swallows of liquid and solid boluses, and the association of the perception with changing of esophageal contraction and/or transit in a specific swallow. Our hypothesis was that the perception of esophageal transit may be associated with changing of esophageal transit and/ or esophageal contractions.

\section{METHOD}

Esophageal contraction, transit and perception were evaluated in 11 asymptomatic volunteers, 4 men and 7 women aged 19-58 years (median: 42 years). They were asymptomatic, did not have digestive, pulmonary or neurologic disease, nor did they have swallowing problems, heartburn or regurgitation. They were recruited by advertisement inside the hospital. The investigation was approved by the Human Research Committee of the University Hospital of 
TABLE 1 . Amplitude and duration of contractions after 22 swallows of a solid bolus and 22 swallows of a liquid bolus performed by 11 asymptomatic volunteers, measured at 5,10,15 and $20 \mathrm{~cm}$ from the lower esophageal sphincter (LES). Mean (SEM)

\begin{tabular}{|c|c|c|c|c|}
\hline & \multicolumn{4}{|c|}{ Distance from LES } \\
\hline & $5 \mathrm{~cm}$ & $10 \mathrm{~cm}$ & $15 \mathrm{~cm}$ & $20 \mathrm{~cm}$ \\
\hline \multicolumn{5}{|l|}{ Amplitude $(\mathrm{mm} \mathrm{Hg})$} \\
\hline Liquid & $104.6(13.5)$ & $77.7(10.0)$ & $40.1(5.5)$ & $59.5(6.5)$ \\
\hline \multicolumn{5}{|l|}{ Solid } \\
\hline Perception & $131.9(16.2)^{*}$ & $102.7(10.4)$ & $49.7(5.9)$ & $82.4(9.9)^{*}$ \\
\hline No perception & $152.6(22.0)^{*}$ & $126.2(14.6)^{*}$ & $85.4(9.6) *$ & $85.6(10.6)^{*}$ \\
\hline \multicolumn{5}{|l|}{ Duration (s) } \\
\hline Liquid & $3.2(0.3)$ & $2.8(0.2)$ & $2.7(0.2)$ & $2.3(0.2)$ \\
\hline \multicolumn{5}{|l|}{ Solid } \\
\hline Perception & $3.6(0.5)$ & $3.4(0.3)$ & $3.5(0.4)$ & $2.7(0.2)$ \\
\hline No perception & $3.5(0.3)$ & $2.7(0.3)$ & $2.8(0.3)$ & $2.0(0.3)$ \\
\hline
\end{tabular}

$* P<0.02$ vs liquid

Ribeirão Preto, SP, Brazil. All volunteers gave written informed consent to participate in the investigation.

The esophageal contraction and transit were measured with a catheter of the Sandhill Scientific Manometry System (Highlands Ranch, CO, USA) that incorporates five pressure (two circumferential and three unidirectional) and four impedance-measuring segments ${ }^{(18)}$. The solid state pressure transducers were placed $5 \mathrm{~cm}$ apart, and the impedance-measuring segment consisted of pairs of metal rings placed $2 \mathrm{~cm}$ apart, centered at the pressure transducers, thus straddling the four proximal pressure transducers. The signal from the catheter was transferred to an amplifying and digitalizing interface (Sensor PAC-Z, Sandhill Scientific Inc), recorded and stored using the dedicated software Insight Acquisition (Sandhill Scientific Inc) and Bio-View Analysis (Sandhill Scientific Inc). The amplitude, duration and area under the curve (AUC) of the contractions, and the time of propagation of peristaltic contractions from $20 \mathrm{~cm}$ to $5 \mathrm{~cm}$ from the lower esophageal sphincter (LES) were analyzed on the manometric tracings and the total bolus transit time (TBTT), bolus head advance time (BHAT), bolus presence time (BPT) and segment transit time (STT) were analyzed on the impedance tracings as previously described ${ }^{(7,18)}$.

The volunteers were studied while sitting on a chair. The catheter was introduced through the nose until the distal circumferential pressure sensor registered the LES pressure. The others pressure sensor registered the pressures at 5, 10, 15 , and $20 \mathrm{~cm}$ from the LES. The impedance values were registered at $5,10,15$, and $20 \mathrm{~cm}$ from the LES. After 5 minutes of stabilization of the recording each volunteer swallowed twice in a random sequence $5 \mathrm{~mL}$ of a liquid bolus (Gatorade, AMBEV, Jaguariúna SP, Brazil), an isotonic drink with $\mathrm{pH}$ 3.3 which was offered in a syringe, and $5 \mathrm{~g}$ to $6 \mathrm{~g}$ of a solid bolus (macaroni), which was chewed before swallowing and was offered in a spoon of $5 \mathrm{~mL}$, both at room temperature.
After the completion of the swallow they were asked about their perception of the bolus passage using a scoring system $^{(13)}: 1$ - bolus passage without perception of transit; 2 - slow transit; 3 - partial blockage; 4 - complete blockage.

The statistical analysis was done by the Center of Quantitative Analysis of the Medical School of Ribeirão Preto USP (CEMEQ) using a linear model with mixed effects ${ }^{(17)}$. The model was adjusted using the Proc Mixed feature of the SAS software package version $9^{(14)}$. The results are reported as mean and standard error (SEM), unless otherwise stated. The differences were considered significant when $P \leq 0.05$ in a two-tailed statistical analysis.

\section{RESULTS}

The 11 volunteers performed 22 swallows of the liquid bolus and 22 swallows of the solid bolus. Perception of bolus transit occurred only with the solid bolus. With the liquid bolus all subjects classified their perception of bolus transit as grade 1, which means that the fluid passed the esophageal body without transit perception. With the solid bolus 12 swallows were classified as grade 1 , seven as grade 2 , three as grade 3 and none as grade 4 . Ten solid bolus swallows were perceived as slow passage or partial blockage.

The amplitude and AUC of contractions were higher after swallows of the solid bolus than after swallows of the liquid bolus. There was no difference in the contraction duration after swallows of the liquid and solid boluses (Table 1). The time for the esophageal peristaltic contraction to propagate from $20 \mathrm{~cm}$ to $5 \mathrm{~cm}$ from the LES was $3.8 \pm 0.5 \mathrm{~s}$ for the liquid bolus and $2.8 \pm 0.3 \mathrm{~s}$ for the solid one $(P>0.05)$. The contractions were peristaltic with both boluses.

The difference between solid and liquid boluses was more evident in swallows with no perception of transit than in swallows with perception in terms of amplitude (Table 1) 


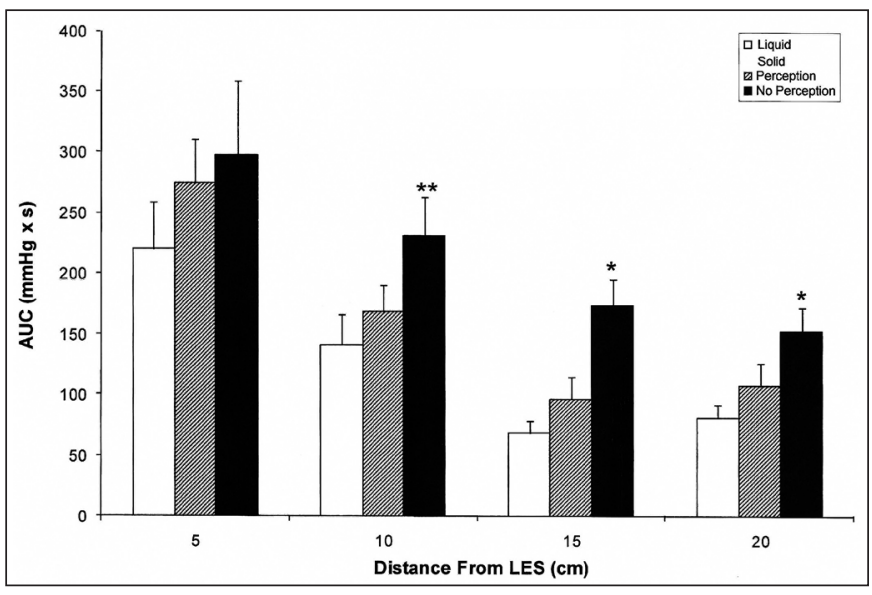

FIGURE 1. Area under the curve (AUC) of esophageal contractions after swallows of a liquid bolus, swallows of a solid bolus with perception of transit and swallows of a solid bolus without perception of transit (Mean and $\mathrm{SEM}) * P<0.01$ vs liquid $* * P=0.07$ vs liquid

and AUC (Figure 1). A significant difference in AUC was observed at $15 \mathrm{~cm}$ and $20 \mathrm{~cm}$ from the LES, with higher values for solid swallows with no perception compared with liquid swallows, a difference not found in swallows with transit perception.

The total bolus transit time was longer for the solid bolus $(8.6 \pm 0.5 \mathrm{~s})$ than for the liquid bolus $(6.5 \pm 0.3 \mathrm{~s}, P<0.01)$, a difference that persisted with solid bolus swallows with no perception $(9.3 \pm 0.6 \mathrm{~s}, P<0.01)$ but not with solid bolus swallows with perception (7.6 $\pm 0.6 \mathrm{~s}, P>0.05)$. The solid bolus causes in the proximal esophagus ( $20-15 \mathrm{~cm}$ from LES) a faster BHAT $(0.6 \pm 0.1 \mathrm{~s})$ than the liquid bolus $(1.4 \pm 0.3 \mathrm{~s}$, $P<0.01)$. Solid swallows followed by no perception of transit had the lowest BHAT $(0.5 \pm 0.1 \mathrm{~s})$, but the difference with liquid swallows and with solid swallows with perception (0.7 $\pm 0.2 \mathrm{~s}$ ) was not significant (Table 2 ). In the distal esophageal

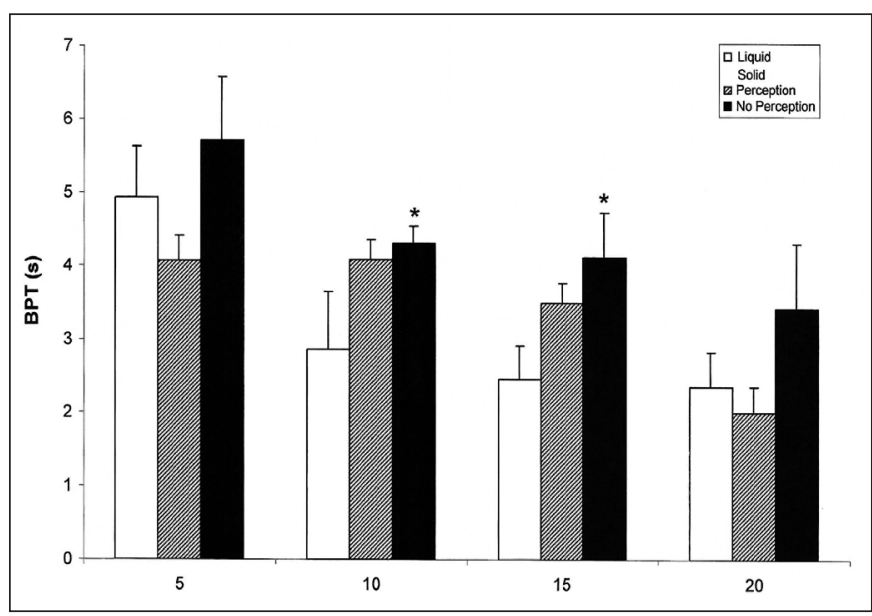

FIGURE 2. Bolus presence time (BPT) after swallows of a liquid bolus, swallows of a solid bolus with perception of transit and swallows of a solid bolus without perception of transit (Mean and SEM) $* P<0.02$ vs liquid

body (10-5 cm from LES) the BHAT was slower in patients with no perception with swallows of a solid bolus $(1.8 \pm 0.3 \mathrm{~s})$ than with swallows of a liquid bolus $(1.5 \pm 0.2 \mathrm{~s}, P=0.05)$. The result for the liquid bolus was similar to that observed with solid bolus swallows with perception $(1.5 \pm 0.2 \mathrm{~s})$.

The segment transit time was longer with the solid bolus than with the liquid bolus (Table $2, P<0.01$ ). Swallows of the solid bolus with no perception of transit had a longer STT from 15 to $10 \mathrm{~cm}$ and from 10 to $5 \mathrm{~cm}$ from the LES than swallows of the liquid bolus $(P=0.04)$. Swallows with perception had a longer STT than liquid swallows from 15 to $10 \mathrm{~cm}$ from the LES (Table 2, $P=0.04$ ). The bolus presence time was also longer with swallows of the solid bolus compared with swallows of the liquid bolus (Figure 2), with statistical significance at 10 and $15 \mathrm{~cm}$ from LES in swallows with no perception $(P<0.02)$.

TABLE 2. Bolus head advance time (BHAT) and segment transit time (STT) after 22 swallows of a solid bolus and 22 swallows of liquid bolus performed by 11 asymptomatic volunteers, measured at 5,10,15 and $20 \mathrm{~cm}$ from the lower esophageal sphincter (LES). Mean (SEM)

\begin{tabular}{|c|c|c|c|}
\hline & \multicolumn{3}{|c|}{ Distance from LES } \\
\hline & $20-15 \mathrm{~cm}$ & $15-10 \mathrm{~cm}$ & $10-5 \mathrm{~cm}$ \\
\hline \multicolumn{4}{|l|}{ BHAT (s) } \\
\hline Liquid & $1.4(0.3)$ & $1.6(0.3)$ & $1.5(0.2)$ \\
\hline \multicolumn{4}{|l|}{ Solid } \\
\hline Perception & $0.7(0.2)$ & $1.5(0.2)$ & $1.5(0.2)$ \\
\hline No perception & $0.5(0.1)$ & $1.6(0.3)$ & $1.8(0.3)^{* *}$ \\
\hline \multicolumn{4}{|l|}{ STT (s) } \\
\hline Liquid & $3.7(0.6)$ & $3.4(0.4)$ & $3.7(0.4)$ \\
\hline \multicolumn{4}{|l|}{ Solid } \\
\hline Perception & $4.0(0.4)$ & $5.4(0.5) *$ & $5.9(0.3)$ \\
\hline No perception & $4.9(0.6)$ & $5.4(0.3) *$ & $7.4(0.6)$ \\
\hline
\end{tabular}

$* P<0.04$ vs liquid

** $P=0.05$ vs liquid 


\section{DISCUSSION}

The swallow of a solid bolus causes an increase in amplitude of contractions and longer bolus transit through the esophagus compared to swallows of a liquid bolus, as described in previous publications ${ }^{(10,12)}$. The contraction propagation was faster with the solid bolus than with the liquid bolus, but the difference did not reach statistical significance. A previous publication reported that the number of non-propagated contractions is higher with a solid bolus than with a liquid bolus ${ }^{(1)}$. This situation could cause a higher incidence of bolus transit perception than that seen with a liquid bolus. However, we did not find non propagated contractions with solid or liquid boluses.

The increase in contraction amplitude and the longer esophageal transit with the solid bolus was more evident in swallows with no perception of esophageal transit than with swallows with perception. In swallows with perception of solid bolus transit the results did not differ from swallows of the liquid bolus. Considering these results, we suggest that there is an adaptation in esophageal contraction and transit when the bolus consistency changes from liquid to solid. If the adaptation is not sufficient it is possible that the subject perceived the bolus transit through the esophagus.

Patients with non-obstructive dysphagia show poor agreement between perception of dysphagia, results of esophageal manometry and results of impedance evaluation of transit, with swallows of liquid and viscous boluses, suggesting that in these patients motor dysfunction has a limited role in the generation of dysphagia ${ }^{(3)}$. A viscous bolus provokes more perception of dysphagia than a liquid bolus ${ }^{(3)}$. The perception of transit in patients with gastroesophageal reflux disease and healthy volunteers was not associated with alteration of esophageal contraction or transit ${ }^{(13)}$. This investigation, performed in patients with gastroesophageal reflux disease, concluded that there is no agreement between objective measurements of esophageal function and subjective perception of bolus passage, suggesting that increased bolus passage perception in patients without mechanical obstruction or esophageal dysmotility might be due to esophageal sensitivity ${ }^{(13)}$.

A single swallow of a solid bolus does not completely clear the bolus from the esophagus and the efficacy of solid bolus clearance in normal individuals is significantly lower than that of a liquid bolus. Also the peristaltic clearing mechanism is much less effective with a solid bolus than with a liquid one ${ }^{(16)}$. A solid bolus elicits distinct esophageal contractile responses than a liquid bolus ${ }^{(12)}$, a fact that should be a physiological adaptation to the bolus consistency. If the adaptation does not occur the subjects may have the sensation consequent to the bolus transit. There is a poor relationship between subjective and objective measures of esophageal clearance ${ }^{(16)}$.

The present results suggest that the duration of esophageal contraction may be increased in the middle esophagus with swallows of a solid bolus followed by perception of bolus transit, but the comparison with swallows that do not cause perception did not reach statistical significance. In a study of esophageal motility in patients with Chagas' disease, a disease consequent to the loss of neurons of the esophageal myenteric plexus ${ }^{(9)}$, an increase in esophageal contraction duration was found in patients with dysphagia, peristaltic esophageal contractions and normal esophageal radiologic transit ${ }^{(5)}$.

In a group of patients with non-obstructive dysphagia, a variation of the causes of the sensation was described. In testing the symptom and esophageal sensitivity, evaluated by the balloon distension test, a solid bolus but not a liquid bolus caused dysphagia, $42 \%$ of the patients had the association of abnormal sensitivity and abnormal motor pattern, $26 \%$ had isolated motor abnormalities, $21 \%$ had isolated abnormal sensitivity, and $11 \%$ had no abnormalities ${ }^{(2)}$.

Perception of bolus passage is determined by the level of stimulation of sensory receptors in the esophageal wall, the sensitivity status of afferent pathways and the cortical processing of the information ${ }^{(15)}$. However, in these normal volunteers there was no clear demonstration of alteration of esophageal sensitivity. The absence of bolus adaptation in some swallows, in contractions and transit, should cause the transit perception. This inadequate adaptation was demonstrated in patients with esophageal motor disorders caused by Chagas' disease and dysphagia ${ }^{(4,6)}$. Age and gender have influence on swallowing behavior ${ }^{(8)}$, and may also influence the perception of bolus passage, hypothesis that need further investigation.

The investigation has some limitations. The number of swallows performed by each volunteers was only four. The manometric examination cause some discomfort to the volunteers, so we have to avoid the long duration of the examination. The four point sensor manometry could miss a localized alteration of the esophageal motility and transit. However, the method is able to register esophageal motility and transit.

In conclusion, the present results suggest that the perception of esophageal transit after swallows of a solid bolus may be the consequence of inadequate adaptation of esophageal transit and contraction to the characteristic of the bolus. 
Dalmazo J, Aprile LRO, Dantas RO. Contrações esofágicas, trânsito do bolo e percepção do trânsito após deglutições de bolos líquido e sólido em voluntários normais. Arq Gastroenterol. 2012;49(4):250-4.

RESUMO - Contexto - Disfagia esofágica é a sensação de que o alimento ingerido tem trânsito lento ou é bloqueado em sua passagem para o estômago. Nem sempre o sintoma é associado com alterações em trânsito ou motilidade. Objetivos - Avaliar, em voluntários normais, a possibilidade de percepção do trânsito através do esôfago de bolo sólido e líquido, as diferenças nas contrações esofágicas e no trânsito pelo esôfago com estes bolos, e a associação entre percepção do trânsito com alterações nas contrações e/ou trânsito. Métodos - Foram estudados 11 voluntários assintomáticos, 4 homens e 7 mulheres com idades entre 19 e 58 anos. Os voluntários foram avaliados na posição sentada. Eles deglutiram, em duplicata, o mesmo volume de bolo sólido (macarrão) e líquido (bebida isotônica). Após cada deglutição foi perguntado sobre sensação da passagem do bolo pelo esôfago. Contrações e trânsito foram avaliados simultaneamente por manometria de estado sólido e impedância. Resultados - Percepção do trânsito ocorreu apenas com o bolo sólido. A amplitude e área sob a curva das contrações foram maiores com a deglutição do bolo sólido do que com a deglutição de bolo líquido. A diferença foi mais evidente nas deglutições em que não houve percepção do trânsito $(n=12)$ do que nas deglutições com percepção $(n=10)$. $O$ tempo total de trânsito foi mais longo para o bolo sólido do que para o bolo líquido somente com as deglutições seguidas pela não percepção do trânsito. Conclusão - Os resultados sugerem que a percepção da passagem do bolo pelo esôfago deve estar relacionada à adaptação inadequada das contrações esofágicas e do trânsito às características do bolo deglutido.

DESCRITORES - Transtornos de deglutição. Esôfago, fisiologia. Alimentos. Água.

\section{REFERENCES}

1. Bernhard A, Pohl D, Fried M, Castell DO, Tutuian R. Influence of bolus consistency and position on esophageal high-resolution manometry findings. Dig Dis Sci. 2008;53:1198-205.

2. Bohn B, Bonaz B, Gueddah N, Rolachon A, Papillon E, Bost R, Fournet J. Oeosphageal motor and sensitivity abnormalities in non-obstructive dysphagia. Eur J Gastroenterol Hepatol. 2002;14:271-7.

3. Chen CL, Yi CH. Clinical correlates of dysphagia to oesophageal dysmotility: studies using combined manometry and impedance. Neurogastroenterol Motil. 2008;20:611-7.

4. Dalmazo J, Dantas RO. Esophageal contractions after wet and dry swallows in patients with esophagitis, Chagas' disease and idiopathic achalasia. Gastroenterol Res. 2010;3:156-62.

5. Dantas RO. Dysphagia in patients with Chagas' disease. Dysphagia. 1998;13:53-7.

6. Dantas RO, Deghaide NH, Donadi EA. Esophageal motility of patients with Chagas' disease and idiopathic achalasia. Dig Dis Sci. 2001;46:1200-6.

7. Dantas RO, Alves LMT, Nascimento WV. Effect of bolus volume on proximal esophageal contractions of patients with Chagas' disease and patients with idiophatic achalasia. Dis Esophagus. 2010;23:670-4.

8. Dantas RO, Alves LMT, Santos CM, Cassiani Rde A. Possible interaction of gender and age on human swallowing behavior. Arq Gastroenterol. 2011;48:195-8.

9. de Oliveira RB, Troncon LE, Dantas RO, Menghelli UG. Gastrointestinal manifestations of Chagas' disease. Am J Gastroenterol. 1998;93:884-9.
10. Johnston BT, Colins JS, McFarland RJ, Blackwell JN, Love AH. A comparison of esophageal motility in response to bread swallows and water swallows. Am J Gastroenterol. 1993;88:351-5.

11. Johnston BT, Castell DO. Symptom overview and quality of life. In: Castell DO, Richter JE, editors. The esophagus. 4th edition. Philadelphia: Lippincott Williams \& Wilkins; 2004. p.37-46.

12. Keren S, Argaman E, Golan M. Solid swallowing versus water swallowing: manometric study of dysphagia. Dig Dis Sci. 1992;37:603-8.

13. Lazarescu A, Karamanolis G, Aprile L, De Oliveira RB, Dantas R, Sifrim D. Perception of dysphagia: lack of correlation with objective measurements of esophageal function. Neurogastroenterol Motil. 2010;22:1292-7.

14. Little RC, Milliken GA, Stroup WW, Wolfinger RD. SAS system for mixed models. Cary, NC: SAS Institute; 1996.

15. Mayer EA. Spinal and supraspinal modulation of visceral sensation. Gut. 2000;47(Suppl. 4):69-72.

16. Pouderoux P, Shi G, Tatum RP, Kahrilas PJ. Esophageal solid bolus transit: studies using concurrent videofluoroscopy and manometry. Am J Gastroenterol. 1999; $94: 1457-63$.

17. Schall R. Estimation in generalized linear models with random effects. Biometrika. 1991;78:719-27.

18. Tutuian R, Vela MF, Shay SS, Castell DO. Multichannel intraluminal impedance in esophageal function testing and gastroesophageal reflux monitoring. J Clin Gastroenterol. 2003;37:206-15. 